\title{
ВЛИЯНИЕ ПАНДЕМИИ COVID-19 НА ЭКОНОМИКУ КЫРГЫЗСКОЙ РЕСПУБЛИКИ
}

\author{
Сансызбаева Гулим Абдрашовна \\ к.э.Н., доцент \\ Мамбетайсаева Керемет \\ Жоодатбекова Созул
}

Кыргызский экономический университет имени М. Рыскулбекова

\begin{abstract}
Аннотация: Пандемия COVID-19 стала серьезным неожиданным фактором для мировой экономической системы. Все страны понесли экономический ущерб из-за резкого увеличения числа заражений и усилий правительства по сдерживанию эпидемии. Кыргызстан не стал исключением, более того, Кыргызстан по итогам года окажется в числе стран, сильнее всех пострадавших от пандемии и сталкивается с рядом неотложных и сложных вызовов.
\end{abstract}

В представленной статье рассматривается базовые показатели экономики КР во время пандемии и какие итоги ожидают увидеть экономисты.

Ключевые слова: Пандемия, экономика, правительство, доход, расход, бюджет, кризис, государственный долг, экономические прогнозы, анализ, ВВП.

\section{IMPACT OF THE COVID-19 PANDEMIC ON THE ECONOMY OF THE KYRGYZ REPUBLIC}

\section{Sansyzbaeva Gylum Abdrashovna Mambetaisaeva Keremet Joodatbekova Sozul}

\footnotetext{
Abstract: The COVID-19 pandemic has become a major factor for the global economic system. All countries suffered economic damage due to a sharp increase in the number of new infections and government efforts to contain the epidemic. Kyrgyzstan is no exception, moreover, by the end of the year, Kyrgyzstan will be among the countries most affected by the pandemic and is facing a number of urgent and complex challenges.
} 
This article examines the basic indicators of the Kyrgyz economy during a pandemic and what results economists expect to see.

Key words: Pandemic, economy, government, income, expenditure, budget, crisis, public debt, economic forecasts, analysis.

В странах Центральной Азии COVID-19 появился относительно поздно. Если в Европе и других странах распространение заболевания началось в январе/феврале, то в Кыргызстане первый случай заражения был зарегистрирован 18 марта, что давало существенное время властям КР подготовится к приходу вируса. Но, к сожалению, Кыргызстан оказался совсем не готов к росту числа инфицированных. В относительно короткие сроки, число заболевших резко возросло. Основный пик по количеству заболевших и погибших пришлось на июнь-июль. В это же время в Кыргызстане действовал жесткий карантин, что повлекло за собой потери для большого количества бизнеса, a также необходимость для многих предприятий отправлять людей на удаленную работу, что в сумме оказало очень негативное влияние на предпринимательскую деятельность в Кыргызстане.

Важно отметить, что по последним имеющимся данным, затраты на здравоохранение в среднем в Центральной Азии составили $6,3 \%$ ВВП или порядка 740 долларов США на душу населения согласно курсу на основе паритета покупательной способности. Естественно, при такой небольшой сумме значительное количество населения не может позволить себе хорошее лечение, и в случае наступления пандемии, может оказать значительное давление на экономику, что мы и видели в итоге в Кыргызстане во второй половине 2020 года. Карантин привел к полному параличу экономики и дефициту в бюджете.

В связи с разразившейся пандемией коронавируса экономические прогнозы по всему миру, в том числе в Кыргызстане, резко ухудшились. Столкнувшись с существенными потерями в основных секторах экономики КР - туризме, торговле, потребительских услугах и строительстве - валовой внутренний продукт страны в 2020 году, как ожидается, сократится на целых $10 \%$, что сказывается кардинально на доходности государственного бюджета. В частности, официальные власти говорят о выпадении почти 35 млрд. сомов (около 412 млн долларов США по курсу от 16 ноября), эксперты же утверждают, что казна недополучит почти половину своего объема, то есть 
почти 85 млрд. сомов (около чуть более 1 млрд. долларов США по курсу от 16 ноября).

Из данных Бюллетеня Национального банка Кыргызской Республики (НБКР) за 9 месяцев 2018-2020 гг., приведенных в таблице 1, можно сделать определенные выводы, каким образом пандемия повлияла на экономику Кыргызстана.

Таблица 1

Макроэкономические показатели КР за 2018-2020 гг.

\begin{tabular}{|l|c|c|c|}
\hline \multicolumn{1}{|c|}{ Показатели } & на 1.09.2018 & на 1.09.2019 & на 1.09.2020 \\
\hline Темп прироста реального ВВП & 1.3 & 6.5 & -5.6 \\
\hline Индекс потребительских цен & 100.9 & 102.3 & 105.3 \\
\hline $\begin{array}{l}\text { Дефицит государственного бюджета по } \\
\text { отношению к ВВП }\end{array}$ & 0.1 & -0.1 & -4.2 \\
\hline $\begin{array}{l}\text { Государственный внешний долг по } \\
\text { отношению к ВВП }\end{array}$ & 46,5 & 45,0 & 55,2 \\
\hline
\end{tabular}

Источник: Бюллетень Национального Банка Кыргызской Республики.

Как видим из таблицы 1, экономика страны в текущем году испытывает глубокий спад со всеми вытекающими последствиями: рекордный дефицит государственного бюджета, резкий рост госдолга, значительные показатели инфляции.

Снижение темпов роста ВВП обусловлено сокращением в промышленности, строительстве и сфере услуг (табл. 2).

Таблица 2

ВВП по видам экономической деятельности в январе-октябре 2020 года

\begin{tabular}{|c|c|c|c|c|}
\hline \multirow[t]{2}{*}{ Показатели } & \multirow[t]{2}{*}{ Млн. сомов } & \multirow{2}{*}{$\begin{array}{c}\text { Темпы роста } \\
\text { (снижения) ВВП }\end{array}$} & \multicolumn{2}{|c|}{ В процентах к итогу } \\
\hline & & & 2019 & 2020 \\
\hline ВВП & 456657,9 & 92,6 & 100,0 & 100,0 \\
\hline Отрасли, производящие товары & 204401,2 & 96,3 & 40,1 & 44,7 \\
\hline Отрасли, оказывающие услуги & 201759,6 & 89,4 & 45,7 & 44,2 \\
\hline налоги на продукты & 50497,1 & & 14,2 & 11,1 \\
\hline
\end{tabular}

Республики. Эл. ресурс http://www.stat.kg/ru/news/valovoj-vnutrennij-produkt-vyanvare-oktyabre-2020-goda/ 
Как видим из данных таблицы 2 Валовой внутренний продукт в январеоктябре текущего года составил 456,7 млрд. сомов, что на 7,4 процентных пункта ниже по сравнению с январем-октябрем прошлого года. При этом, темпы роста отраслей, производящих товары (реальный сектор) по сравнению с январем-октябрем прошлого года снизились на 3,7 процента. Ещё большее снижение по сравнению с январем-октябрем 2019 года наблюдается в отраслях, оказывающих услуги - 10,6 процента.

В январе-октябре текущего года в структуре ВВП доля отрасли реального сектора экономики по сравнению с тем же периодом прошлого года увеличилась на 4,6 процентных пункта и составила 44,7 процента. Что касается отраслей, оказывающих услуги, то по сравнению с январем-октябрем 2019 года их доля в ВВП, напротив, сократилась на 1,5 процента и составила 44,2 процента.

При всей нестабильности экономики Кыргызстана с момента обретения независимости, это самое значительное падение за 26 лет, с 1994 года, когда экономика молодого государства потеряла около $20 \%$ по сравнению с предыдущим годом. Одними из главных жертв нынешней ситуации в экономике Кыргызстана стали сфера производства нефтепродуктов, которая зафиксировала падение на 55,1\% (по отношению к предыдущему году), текстильное производство, производство одежды и обуви - падение на 22,3\% (так же по отношению к показателем предыдущего года). Объемы добычи полезных ископаемых снизились на 16,8\%.

По данным Центрального казначейства Кыргызской Республики общие доходы республиканского бюджета на 2020 год ожидаются в сумме 137 млрд 131,4 млн сомов. Общие расходы республиканского бюджета ожидаются в сумме 172 млрд 772,8 млн сомов, а дефицит бюджета ожидается в сумме 35 млрд 641,4 млн сомов — с увеличением на 7 млрд 949,1 млн сомов от прогноза в июне. Дефицит бюджета вырос на 8 млрд сомов и достиг уже 35, 6 млрд сомов, что составляет более $8 \%$ ВВП страны. На это повлияли сокращения доходной части бюджета, пандемия коронавируса, закрытие границ с другими странами, режим ЧП, карантинные меры и политические потрясения октября 2020 года.

Как пополнить бюджет? При высоком дефиците госбюджета и приостановлении внешней помощи, государственными органами изыскиваются внутренние резервы пополнения бюджета. Кроме того, и.о. президента, премьер - министр Садыр Жапаров объявил экономическую 
амнистию, согласно которой за 30 дней коррумпированным чиновникам, руководителям департаментов, таможенным служащим, финансистам и уклоняющимся от налогов лицам было предложено добровольно вернуть незаконно полученные средства в Казначейство.

Ещё, власти республики рассчитывают на то, что граждане помогут ей с покрытием дефицита бюджета и погашением внешнего долга - открытием специального депозитного счета поступающих пожертвований, добровольных взносов от физических и юридических лиц, которые согласно поручению правительства будут направлены на обозначенные нужды.

Индекс потребительских цен. Инфляция в 2020 году ожидается на уровне 10.8\% против утвержденного ранее показателя в 3.7\% (в \% к декабрю предыдущего года). Об этом говорится в уточненном проекте законе «О республиканском бюджете на 2020 год и прогнозе на 2021-2022 годы», что больно ударит по населению Кыргызстана, особенно для малоимущих семей. За рассматриваемый период, больше всего цены выросли на продукты питания. На коммунальные услуги и непродовольственные продукты цены также заметно выросли.

Состояние валюты во время пандемии.

Падение мировых цен на нефть привело к снижению курса российского рубля и казахского тенге, то есть стран - партнеров по Евразийскому Союзу, и основными партнерами Кыргызской Республики. Это вызвало значительное снижение курса кыргызского сома по отношению к доллару США, и официальный обменный курс 11 марта 2020 года снизился с 69,85 до 84,9 сома всего лишь 3 недели спустя. К началу мая курс стабилизировался на уровне чуть ниже 1 долл. США = 80 сомов (обратите внимание, что данная оценка воздействия основана на предполагаемом среднегодовом обменном курсе 1 долл. США = 80 сомов на 2020 год).

После некоторой стабилизации, выпавшей на период с конца весны по лето, осенью, особенно после политических потрясений, курс доллара снова подскочил до показателя 1 долл. США = 84,5 сомов. При этом обменный курс евро 9 октября, впервые преодолел психологическую цифру 1 евро = 100 сом.

В силу сравнительно небольших размеров и, как правило, низкого уровня диверсификации, экономика Кыргызстана в значительной мере зависит от внешней торговли. Режим карантина в КНР и закрытие границ привели к снижению импорта Кыргызской Республики (в долларовом выражении) на 30\% за первые 4 месяца 2020 года (эта оценка воздействия 
основана на прогнозируемом сокращении общего импорта товаров и услуг на $10 \%$ в 2020).

Данные за январь-сентябрь 2020 года показывают, что пандемия COVID-19 уже усугубила фискальную ситуацию в Кыргызской Республике. По данным Министерства финансов, по сравнению с аналогичным периодом 2019 года доходы государственного бюджета сократились на 12,7 млрд. сомов (достигнув 79\% от уровня 2019 года).

Таблица 3

Основные параметры республиканского бюджета. млрд.сом

\begin{tabular}{|l|c|c|c|}
\hline & $\begin{array}{c}2019 \\
\text { Факт }\end{array}$ & $\begin{array}{c}2020 \\
\text { Первонач }\end{array}$ & $\begin{array}{c}2020 \\
\text { Пересмотр }\end{array}$ \\
\hline Всего доходов & $\mathbf{1 4 8 . 5}$ & $\mathbf{1 6 3 . 7}$ & $\mathbf{1 3 5 . 3}$ \\
\hline Налоговые доходы & 105.9 & 127.9 & 94.6 \\
\hline Налоги на доходы & 11.9 & 11.1 & 8.1 \\
\hline НДС на отечественное производство & 12.1 & 16.4 & 12.3 \\
\hline НДС на импорт & 38.8 & 51.0 & 36.8 \\
\hline Акцизы на импорт & 8.7 & 12.0 & 7.7 \\
\hline Налоги на внешнюю торговлю & 22.0 & 22.7 & 18.8 \\
\hline $\begin{array}{l}\text { Прочее (налог на доход Кумтора, налог с продаж, внутренние } \\
\text { акцизы) }\end{array}$ & 12.5 & 14.7 & 13.8 \\
\hline Официальные трансферты & 13.5 & 9.7 & 12.8 \\
\hline Неналоговые доходы & 29.1 & 26.1 & 25.7 \\
\hline Всего расходов & $\mathbf{1 4 9 . 3}$ & $\mathbf{1 7 1 . 7}$ & $\mathbf{1 6 3 . 0}$ \\
\hline Заработная плата работников & 47.7 & 59.3 & 58.8 \\
\hline Приобретение товаров и услуг & 19.4 & 24.0 & 21.1 \\
\hline Трансферты во внебюджетные фонды, местные бюджеты & 34.7 & 36.1 & 36.5 \\
\hline Социальные пособия & 9.9 & 9.9 & 10.2 \\
\hline Капитальные вложения & 26.5 & 29.6 & 23.7 \\
\hline Другие расходы & 11.0 & 12.7 & 12.8 \\
\hline Дефицит & $\mathbf{- 0 . 9}$ & $\mathbf{- 8 . 0}$ & $\mathbf{- 2 7 . 7}$ \\
\hline Субсидии ГП & 3,2 & 5.3 & 21.5 \\
\hline Общий бюджетный баланс (дефицит за вычетом кредитов) & -4.1 & -13.3 & -48.2 \\
\hline Внешнее финансирование & 2.9 & 4.8 & 38.5 \\
\hline Новые займы & 13.1 & 16.7 & 51.6 \\
\hline Погашение & -10.1 & -11.8 & -13.1 \\
\hline Номинальный ВВП & 590.0 & 667.1 & 583.2 \\
\hline $\begin{array}{l}\text { Расходы на здравоохранение, финансируемые из } \\
\text { республиканского бюджета (включая трансферты в ФОМС) }\end{array}$ & 14.3 & 15.6 & 18.1 \\
\hline
\end{tabular}


Источник: Закон „О внесении изменений в Закон КР „О республиканском бюджете Кыргызской Республики на 2020 год и прогнозе на

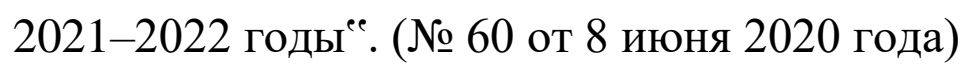

Почти $50 \%$ всех потерь доходов связаны всего с двумя налоговыми потоками: налог на добавленную стоимость на импорт из стран, не входящих в ЕАЭС, и налоги на международную торговлю. Оба этих налоговых потока включают импорт из КНР в качестве ключевого компонента их налоговой базы. Как упоминалось ранее, импорт из КНР резко сократился в начале 2020 года, равно как и налоговые поступления от этого импорта. В то же время, расходы государственного бюджета увеличились на 2,6 млрд. сомов по причинам, не связанным с COVID-19. Это включало увеличение расходов на заработную плату в секторе образования и капиталовложения в рамках Программы государственных инвестиций страны. Так, в январе-сентябре 2020 года по сравнению с аналогичным периодом 2019 года баланс государственного бюджета ухудшился на 15,3 млрд. сомов.

Таким образом, правительство КР сегодня оказалось между молотом и наковальней. С одной стороны - из-за кризиса, связанного с коронавирусом, необходимо оказать поддержку бизнесу, но с другой - совсем освободить их от налогов тоже не получается. Единственное, в чем власти пошли на уступки, так это освободили предпринимателей от пени и штрафов, а также отсрочили уплату страховых взносов. Кроме того, были снижены тарифы по социальному обеспечению для малого и среднего бизнеса. А также продлены мораторий на проверки и сроки уплаты налогов.

Мы рассмотрели, какие промежуточные итоги мы можем подвести на данный момент по влиянию пандемии короновируса на экономику Кыргызской Республики. По всем показателям, экономика столкнулась с одним из величайших кризисов в истории страны. Сейчас перед руководством страны стоит задача преодолеть негативные явления в экономике, решить социально-экономические проблемы, связанные с пандемией коронавирусной болезни (COVID-19), путем решительных действий, включающих поиск новых путей укрепления экономических секторов, привлечение инвестиций, поддержка малого бизнеса, расширение возможностей занятости населения.

\section{Список литературы}

1. COVID-19 грозит ввергнуть мировую экономику в тяжелейшую рецессию со времен Второй мировой войны - Всемирный Банк

2. Stat.kg - сайт Национального Статистического Комитета 
3. Minfin.kg - сайт Министерства Финансов Кыргызской Республики

4. Nbkr.kg - Национальный Банк Кыргызской Республики

5. kenesh.kg - сайт Жогорку Кенеша КР

6. Татьяна Кудряцова. Пандемия коронавируса. Что ждет экономику Кыргызстана / Т.Кудряцева // 24.kg -2020.

7. Эрнист Нурматов. Кризис экономики КР из-за COVID-19. Неутешительные прогнозы и туманные перспективы / Э. Нурматов // Азаттык. - 2020. https://rus.azattyk.org/a/covid-19 v kyrgyzstane krizis ekonomiki/ 30543491.html 